\title{
Grain growth of maize after local application of subzero temperature : thermal properties of ears
}

\author{
Jean-François LEDENT \\ with the collaboration of Thierry BoItTe, Isabelle De Keyzer, Jean-François Detry, Etienne Duveiller \& \\ Astrid WAUCQUEZ
}

Université Catholique de Louvain, ECOP, 2, place Croix du Sud, B-1348 Louvain-la-Neuve, Belgique

\begin{abstract}
The direct effect of subzero temperature on the ear of maize during grain filling was tested in the field over several years. Artificially cooling only the ear to maintain a temperature of $-2{ }^{\circ} \mathrm{C}(-1$ to -3$)$ for $45 \mathrm{~min}$ at the grain surface (below the husk) without influencing the temperature of the rest of the plant, reduced subsequent grain growth rate by $22 \%$. A drastic reduction ( $80-90 \%$ ) was observed when the treatment temperature was $-5{ }^{\circ} \mathrm{C}(-4$ to -6$)$. Crude estimates of the thermal characteristics of ears, based on their rate of cooling in cold air, are presented.
\end{abstract}

Additional key words : Frost, kernel weight, cold, thermal properties, Zea mays $L$.

Croissance du grain de maïs après l'application locale de température inférieure à zéro ; propriétés thermiques.

L'effet direct de températures inférieures à zéro durant la croissance du grain fut étudié en champ plusieurs années.

En maintenant une température de $-2{ }^{\circ} \mathrm{C}\left(-1\right.$ à $\left.-3{ }^{\circ} \mathrm{C}\right)$ pendant 45 min à la surface du grain (sous les spathes) tout en n'influençant pas la température du reste de la plante, on réduit le taux de croissance du grain après traitement, de $22 \mathrm{p}$. 100 en moyenne. Une réduction drastique $(80-90 \mathrm{p} .100)$ est observée quand la température de traitement est de $-5^{\circ} \mathrm{C}\left(-4\right.$ à $\left.-6^{\circ} \mathrm{C}\right)$.

Des estimations grossières des caractéristiques thermiques des épis, calculées à partir de leur vitesse de refroidissement dans de l'air froid, sont présentées.

Mots clés additionnels : Gel, poids du grain, froid, caractéristiques thermiques, Zea mays $L$.

\section{INTRODUCTION}

Maize (Zea mays L.) is frost-sensitive in all phases of its development including grain filling and ripening (MIEDEMA, 1982). Subzero temperatures may affect kernel growth through direct effects on kernel and ear tissues and/or indirectly through effects on other parts of the plant such as decreased supply of assimilates due to foliage destruction, reduction of translocation due to damage to stem or shank tissue. The effects of light frost $\left(-1,-2{ }^{\circ} \mathrm{C}\right)$ on maize were reported to be similar to those of defoliation, whereas damage to stem or peduncle tissue occurred only at lower temperatures (DAYNARD et al., 1980). In other cereal species also, stem tissues are not markedly affected by light frost. In wheat for instance freezing the stem at temperatures of -2.5 to $-5{ }^{\circ} \mathrm{C}$ for 4 to $20 \mathrm{~min}$ had no effect on grain size on quality (BANATH \& SINGLE,
1976). Moreover in maize the capacity of phloem to translocate assimilates was only weakly affected by the local application of temperatures as low as $-1{ }^{\circ} \mathrm{C}$ (FAUCHER \& BONNEMAIN, 1981). Thus in the case of a light frost, grain growth is unlikely to be prevented due to drastic effects on translocation. Assimilates from still functional leaves (if any) or from remobilization of stem materials may therefore continue to be supplied to the kernels after a frost. Such remobilization is commonly observed in cool climates with low light intensity at the end of the season (DAYNARD et al., 1969 ; STRUIK, 1983).

Grain growth should therefore not be prevented unless the grain itself was directly affected by the frost. Direct effects of low subzero temperature on ears or kernels are indeed reported but little is said of the effects on subsequent grain filling.

Temperatures of $-4{ }^{\circ} \mathrm{C}$ are known to cause direct 
damage to immature kernels of maize (EDEY, 1975 ; BARLOY, 1984). The effects usually described are those on germination capacity or seedling vigour obtained with seed harvested on an ear subjected to subzero temperature at different stages during ripening.

ROSSMAN (1949), for instance, subjected detached maize ears, harvested at different maturity levels to various subzero temperatures. Air temperatures of - $3.3{ }^{\circ} \mathrm{C}$ for 0 to $8 \mathrm{~h}$ were without effect on subsequent germination capacity because of the protective effect of the husk. Only when kernel temperatures were as low as $-3.6{ }^{\circ} \mathrm{C}\left(-6,-7{ }^{\circ} \mathrm{C}\right.$ air temperature) for more than $2 \mathrm{~h}$, and ears were immature, was there a significant reduction of germination capacity (no effect at $60 \%$ dry matter content (DM) ; reduction of $40 \%$ at $40 \% \mathrm{DM}$ ).

Similar studies conducted with other species such as soybeans gave the same type of results (JUDD et al., 1982). They showed subzero temperature to be more detrimental at low dry-matter content and when grains remained attached to the plant, because of a lesser ability for supercooling. Transient supercooling to $4{ }^{\circ} \mathrm{C}(2$ to $7^{\circ}$ ) below freezing temperature is indeed common in plant tissues (LARCHER et al., 1985). In soybean for instance immature seeds in green pods on the plant supercool hardly at all whereas seeds in yellow pods supercool 2.5 to $2.8{ }^{\circ} \mathrm{C}$ (JUDD et al., 1982). However protection of ears from external freezing nuclei, due to enclosure of ears within other plant parts (leaf sheaths before ear emergence) or plastic bags helps prevent ice formation in tissues and therefore limits damage at temperatures as low as $-3.9{ }^{\circ} \mathrm{C}$ (experiments with wheat, SiNGLE \& MARCELLOS, 1974).

Our objective was to determine if short periods at subzero temperatures had direct effects on subsequent grain growth (independently of foliage destruction or damage to stem tissue). We therefore studied the effect of subzero temperatures applied only to the ears (still attached to the plants). We tested the effects of light frosts which were not likely to involve actual formation of ice within grain or cob tissue. Only the ears were treated. This made it possible to avoid indirect effects due to frost damage on other plant parts, and the propagation of an ice front from other plant parts to the grain through the vessels.

We also tested the effects of more drastic frosts $\left(-5{ }^{\circ} \mathrm{C}\right)$ which are known to cause serious damage to the kernels as shown by their reduced subsequent germination capacity.

Finally we determined some of the thermal characteristics of ears, which determine how cool air temperature affects temperature within the ear.

Grains are indeed protected by the husks. Due to thermal characteristics of the ear, grain temperature may differ from air temperature, especially when air temperature cools rapidly to subzero temperature. Thermal characteristics of ears may therefore be important for frost damage in grains.

\section{MATERIALS AND METHODS}

\section{A. Plant material}

Experiments were conducted on plants growing in farmers fields located around Louvain-la-Neuve (Belgium) (on sandy-loamy soil), exp. 1 to 5 , or in SartEustache (Condroz region, Belgium) exp. 6. All varieties were flintdent hybrids adapted to local conditions, with an FAO index of precocity between 200-250. Usual cropping techniques were applied: (70 to $150 \mathrm{~kg} / \mathrm{ha} \mathrm{N}$, etc.), weed control with atrazine, ... Population density was 80000 to 90000 plants per ha in all experiments. Silk extrusion occured between 1 and 10 August according to the experiment. In September, groups of plants were visually selected for uniform total height and ear size. Each group was considered as a block. The number of groups varied from 5 to 24 (table 1). In experiment 2 there were 5 plants per group for each treatment, whereas in other experiments there was only one for each treatment (each group contained one pair of plants : one treated plant and one control).

\section{B. Cold treatment}

A double walled cylinder made of a piece of plastic pipe (outer wall ; length $30 \mathrm{~cm}$, diameter $15 \mathrm{~cm}$ ) and a plastic bag (inner wall) was placed around the ear (still attached to the plant). Water-tightness of the double walls was insured with a sealing ring placed at the lower end of the cylinder. A cooling mixture made of crushed ice, water and salt (about $-16^{\circ} \mathrm{C}$ ) was placed between the double walls through the upper ope-

TABLE 1

Varieties, years, sample size.

Variétés, années d'expérimentation, taille des échantillons.

\begin{tabular}{cccccc}
\hline \hline $\begin{array}{c}\text { Experiment } \\
\text { Expérience }\end{array}$ & $\begin{array}{c}\text { Variety } \\
\text { Variétés }\end{array}$ & $\begin{array}{c}\text { Years } \\
\text { Années }\end{array}$ & $\begin{array}{c}\text { Nb of replicates } \\
\text { Nb de répétitions }\end{array}$ & $\begin{array}{c}\text { Nb of kernels }{ }^{1} \\
\text { Nb de grains }\end{array}$ & $\begin{array}{c}\text { Remarks } \\
\text { Remarques }\end{array}$ \\
\hline 1 & LG7 & 1979 & 11 & 30 & (Jacques Cartier, Anjou 08, Auroch Cuzco, \\
2 & Leader & 1981 & 16 & 15 & Frontenac, Suroit, Anjou 28 $^{2}$ ) \\
3 & Alsa & 1982 & 24 & 15 & \\
4 & Sonia & 1986 & 5 & 15 & \\
5 & LG9 & 1984 & 12 & 40 & 4 \\
6 & Leader & 1982 & 12 & 15 & 4 sowing dates ; 4 dates de semis \\
\hline \hline
\end{tabular}

1 For determination of mean kernel weight (per replicate).

Pour la détermination du poids moyen du grain (par répétition).

2 Additional varieties used for studying the thermal characteristics of ears.

Variétés supplémentaires utilisées pour l'étude des caractéristiques thermiques. 
ning, making the soft inner wall adhere tightly to the ear. An example of the change of temperature during treatment is presented in figure 1 . It generally took $1 \mathrm{~h}$ to reach the temperature required, which was maintained for $45 \mathrm{~min}$ (total duration of treatment was about $1 \mathrm{~h} \mathrm{30)}$. Ambient air temperature varied from 15 to $20{ }^{\circ} \mathrm{C}$ at the time of treatment. This mimicked the change in grain temperature during the occurrence of light night frosts, at least from the moment when the temperature had been reduced to less than $5^{\circ} \mathrm{C}$. The change from $15-20{ }^{\circ} \mathrm{C}$ to $5^{\circ} \mathrm{C}$, however, was much more rapid than in nature. To study the effect of maturity level, and more precisely grain dry matter content, the treatments were applied in the same fields at different dates (exp. 2 to 4, table 2). Different maturity levels at the same date were also compared, using a sowing date trial (exp. 6) with 4 sowing dates (27 April, 9,6 and 27 May). Two different treatment temperatures were tested $-2{ }^{\circ} \mathrm{C}\left(-1\right.$ to $-3{ }^{\circ} \mathrm{C}$; exp. 1 to 4$)$ and $-5^{\circ} \mathrm{C}\left(-4\right.$ to $-6{ }^{\circ} \mathrm{C}$; exp. 5 and 6$)$.

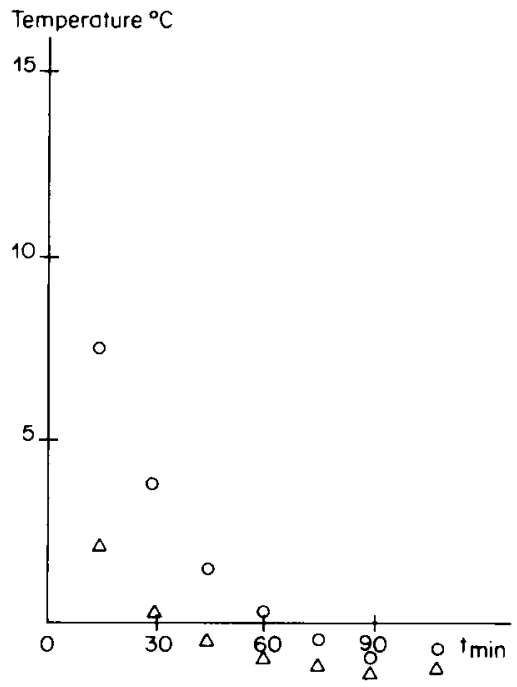

Figure 1

Example of temperature change $\left({ }^{\circ} \mathrm{C}\right)$ at the distal surface of kernels, under the husk $(\Delta)$ and in the centre of the cob (O) during cold treatment; time $t$ is given in minutes.

Exemple de courbe d'évolution de la température $\left({ }^{\circ} \mathrm{C}\right)$ à la surface extérieure des grains sous les spathes $(\Delta)$ et au centre du rachis $(0)$ durant le traitement au froid. Le temps $t$ est donné en minutes.

\section{Measurement of temperature}

Temperatures were monitored using $\mathrm{Ni} \mathrm{Cr}-\mathrm{Cr} \mathrm{Al}$ thermocouple probes $(0.2 \mathrm{~mm}$ diameter $)$ and a Comark 3002 digital thermometer $\left(0.1{ }^{\circ} \mathrm{C}\right.$ readability $)$. Probes were placed along the central axis of the cob, and against the distal surface of the kernels, under the husk. In exp. 2 probes were also placed within the kernels.

\section{Observation of treatment effect on kernel growth, interpretation of results}

After treatment the husks of treated and untreated ears (controls) were gently opened and the distal half of the ear was removed. Fifteen kernels (per ear) were sampled near the broken surface of the half removed and the mean dry weight per kernel (initial kernel weight, IKW) was determined for each ear separately. The husks were placed back into position on the proximal half of the ear (still attached to the plant) until final harvest, when a similar number of kernels were sampled near the broken surface and their dry weight was determined (final kernel weight, FKW). All plants remained in the field until final harvest.

In a secondary experiment the observations were made on intact ears only (distal end not removed), controls being harvested at the time of treatment and at maturity, treated ears being harvested at maturity only. This procedure envolves calculation of grain growth rates from data not corresponding to the same ears at each date. The treatment effects are similar to those obtained with the other method (removal of the distal end) but the residual variation was much higher ; this method was therefore discarded.

Kernel growth rate (KGR) was calculated as :

$$
\mathrm{KGR}=(\mathrm{FKW}-\mathrm{IKW}) / \mathrm{D}
$$

where $\mathrm{D}$ is the number of days between treatment and final harvest.

Values of kernel growth rate (KGR) and final kernel weight $(\mathrm{FKW})$ were subjected to analyses of variance to test the significance of treatment effects (comparison of treated ears and controls). From their mean values the proportions of reduction in final kernel

TABLE 2

Experimental data: dates and dry matter content.

Données expérimentales : dates et teneur en matière sèche.

\begin{tabular}{|c|c|c|c|c|c|c|c|}
\hline \multirow{2}{*}{\multicolumn{2}{|c|}{$\begin{array}{l}\text { Experiment } \\
\text { Expérience }\end{array}$}} & \multirow{3}{*}{$\begin{array}{l}\begin{array}{c}\text { of treatment } \\
\text { du traitement }\end{array} \\
13 / 10\end{array}$} & \multirow{2}{*}{$\begin{array}{l}\text { Date } \\
\text { final harvest } \\
\text { de la récolte finale }\end{array}$} & \multirow{2}{*}{$\begin{array}{l}\text { I } \% \text { DM when treated } \\
\% \text { MS lors du traitement }\end{array}$} & \multicolumn{3}{|c|}{$\%$ DM at final harvest } \\
\hline & & & & & \multicolumn{3}{|c|}{$\begin{array}{l}\text { \% MS lors de la récolte finale } \\
\text { control } \\
\text { témoins } \\
\text { traités }\end{array}$} \\
\hline \multirow[t]{4}{*}{1} & & & $19 / 10$ & 50.0 & 58.3 & 59.0 & $\mathrm{NS}^{2}$ \\
\hline & 2.1 & $02 / 09$ & $30 / 09$ & 15.3 & 47.4 & 45.0 & NS \\
\hline & 2.2 & $09 / 09$ & $30 / 09$ & 18.0 & 43.7 & 43.4 & NS \\
\hline & 2.3 & $24 / 09$ & $30 / 09$ & 39.1 & 42.7 & 41.8 & NS \\
\hline \multirow[t]{2}{*}{3} & 3.1 & $01 / 09$ & $19 / 09$ & 37.8 & 58.5 & 57.6 & NS \\
\hline & 3.2 & $09 / 09$ & $19 / 09$ & 46.6 & 57.6 & 54.3 & NS \\
\hline \multirow[t]{2}{*}{4} & 4.1 & $04 / 09$ & $26 / 09$ & 31.6 & 43.5 & 41.0 & NS \\
\hline & 4.2 & $12 / 09$ & $26 / 09$ & 37.3 & 42.3 & 43.4 & NS \\
\hline
\end{tabular}

\footnotetext{
I $\%$ DM dry matter content of grain $(\%) ; \%$ teneur en matière sèche du grain $(\%)$.

2 NS difference not significant $(\mathrm{p} \leqq 0.05)$; NS : différence non significative $(\mathrm{p} \leqq 0,05)$.
} 
weight $(\mathrm{Re})$ and in kernel growth rate (re) were calculated as:

$$
\begin{aligned}
\mathrm{Re} & =1-\left(\mathrm{FKW}_{\mathrm{t}} / \mathrm{FKW}_{\mathrm{c}}\right) \\
\mathrm{re} & =1-\left(\mathrm{KGR}_{\mathrm{t}} / \mathrm{KGR}_{\mathrm{c}}\right)
\end{aligned}
$$

where the indices $\mathrm{c}$ and $\mathrm{t}$ refer to controls and treated ears, respectively.

Logically it can be expected that the effect on final kernel weight (FKW) of a given reduction of kernel growth rate (KGR) due to treatment will be larger when the treatment is applied earlier, when a smaller amount of grain growth has already been achieved. The relation existing between the reduction in final kernel weight (Re), reduction in kernel growth rate (re), and amount of grain growth already achieved will be used for discussing the results. Indeed if we define the proportion of grain growth already achieved at time of treatment application as the ratio of initial kernel weight to final kernel weight in the controls :

$$
\mathrm{PGAA}=\mathrm{IKW}_{\mathrm{c}} / \mathrm{FKW}_{\mathrm{c}} \text {, }
$$

the following relation may be shown to hold in theory :

$$
\operatorname{Re}=(1-\text { PGAA }) \times \text { re }(1) .
$$

Difference in initial kernel weight of controls and treated ears introduces some differences between the two members of equation 1 when observed values are introduced. This is due to random variation from ear to ear. Since the difference (less than $5 \%$ ) between $\mathrm{IKW}_{\mathrm{c}}$ and $\mathrm{IKW}_{\mathrm{t}}$ is not statistically significant, observed values of reduction in growth rate (Re) were adjusted to allow equation (1) to hold exactly. Adjustment is made by adding correction factor $\mathrm{CF}$ i.e. replacing $\mathrm{Re}$ by $\mathrm{Re}+\mathrm{CF}$; correction factor $\mathrm{CF}$ is given by :

$$
\mathrm{CF}=\left(\mathrm{IKW}_{\mathrm{t}}-\mathrm{IKW}_{\mathrm{c}}\right) / \mathrm{FKW}_{\mathrm{c}} \text {. }
$$

Discussion of the results will be based on the parameters in equation (1) and on adjusted values of reduction in kernel weight $(\mathrm{Re}+\mathrm{CF})$. Introduction of the correction factor modifies values of Re (reduction in kernel weight) by only a few percent (less than $5 \%$ ) but after correction $\mathrm{Re}$ is exactly consistent with values of other parameters in equation (1).

\section{E. Thermal characteristics of ears}

\section{Rate of cooling}

Intact ears (with husk) from the fields used in exp. 1 and 2 were harvested (final harvest) and stored at $5{ }^{\circ} \mathrm{C}$. Twenty four $\mathrm{h}$ before measurement they were placed in a growth chamber at $25^{\circ} \mathrm{C}$. Measurements started after they were abruptly placed in a large chamber at $5^{\circ} \mathrm{C}$ (air temperature), each ear being attached to a vertical wooden rod. Temperatures at kernel surface (under the husk), in the central axis of the cob (exp. 1 and 2) and within the kernel (exp. 2) were measured continuously with the thermocouple probes mentioned above. Taking into account the equation of heat diffusion during ear cooling we defined :

$$
\mathrm{X}=\ln \left(\left(\mathrm{T}_{\mathrm{t}}-\mathrm{T}_{\mathrm{a}}\right) /\left(\mathrm{T}_{\mathrm{i}}-\mathrm{T}_{\mathrm{a}}\right)\right)
$$

where $T_{a}$ is the constant air temperature during cooling, $T_{i}$ is the homogeneous initial temperature of the ear, and $T_{1}$ is the temperature at time $t$ at a given point within the ear during cooling (transient state, SCHNEI-
DER, 1955). The choice of this transformation is based on equations given by SCHNEIDER (1955) ; CARSLAW \& JAEGER (1959) and describing the evolution of temperature in homogeneous cylinders. In that case $\mathrm{X}$ is shown to be related to time through infinite series involving sums of negative exponentials. After an initial time the series are reported to converge rapidly, and a suitable approximation is given by the first term of the series, which yields a linear plot of $\ln X$ as a function of time (CARSLAW \& JAEGER, 1959). The values of $\mathrm{X}$ through time were determined for three locations within the ear where probes were placed, an example is given in figure 2 .

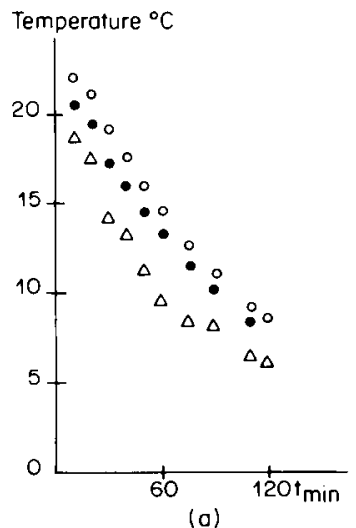

(a)

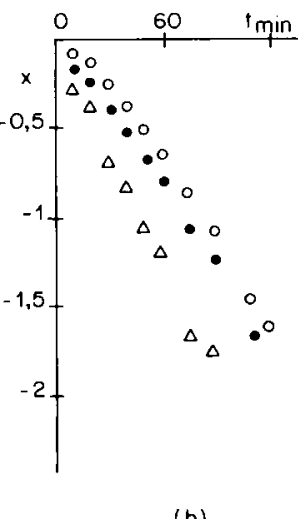

(b)
Figure 2

Example of temperature change in ears initially at $25{ }^{\circ} \mathrm{C}$ and suddenly placed in cool air at $5{ }^{\circ} \mathrm{C}$; figure $2 \mathrm{a}$ : temperature change; figure $2 \mathrm{~b}$ : change of $\left.X=\ln \left[\left(T_{t}-T_{a}\right) / T_{i}-T_{a}\right)\right]$ where $T_{t}$ is the temperature at time $t, T_{a}$ is the temperature of cool air $\left(5^{\circ} \mathrm{C}\right)$ and $T_{i}$ is the initial ear temperature $\left(25^{\circ} \mathrm{C}\right)$; time $t$ is in minutes.

Exemple de l'évolution de la température dans des épis initialement à $25{ }^{\circ} \mathrm{C}$ et soudainement placés dans de l'air froid à $5{ }^{\circ} \mathrm{C}$; figure $2 \mathrm{a}$ : évolution de la température; figure $2 \mathrm{~b}$ : évolution de $X=\ln \left[\left(T_{t}-T_{a}\right) /\left(T_{i}-T_{a}\right)\right]$ où $T_{t}$ est la température du moment $t, T_{a}$ est la température de l'air froid $\left(5^{\circ} \mathrm{C}\right)$ et $T_{i}$ est la température initiale de l'épi $\left(25^{\circ} \mathrm{C}\right)$; le temps $t$ est donné en minutes.
$\Delta$ distal surface of kernels (under the husk)

- within kernels

- centre of cob

\section{- surface extérieure du grain (sous les spathes) \\ - intérieur du grain \\ - centre de la rafle.}

For each ear and each position within the ear separately, cubic polynomials were fitted to the data of $\mathrm{X}$ through time (in $\mathrm{min}$ ) using regression techniques (DRAPER \& SMITH, 1968) :

$$
X=b_{0}+b_{1} t+b_{2} t^{2}+b_{3} t^{3} .
$$

The cubic term was not significant $\left(b_{3}\right.$ not significantly different from zero, $\mathrm{p} \leqq 0.05$, in practically all cases). Furthermore when quadratic polynomials were fitted to the data, altough the quadratic term $\left(b_{2}\right)$ was statistically significant in about half the cases, its values were always very small (absolute value $3 \times 10^{-5}$ ) and very variable (sign and absolute value) from ear to ear. Therefore only the values of coefficient $b_{1}$ were considered in a first approach for characterizing the thermal properties of each ear measured.

The regression of $\mathrm{X}$ on time was not forced through the origin. Indeed plots of experimental data (fig. 2) and theoretical models show deviation from linearity (relation of $\mathrm{X}$ on time) in the first moments following transfer to a lower temperature as compared to later 
(CARSLAW \& JAEGER, 1959; SCHNEIDER, 1955). Extrapolation of the regression line to time zero gives an intercept $b_{0}$, significantly different from zero in about half the cases. For data at the surface of kernels $\mathrm{b}_{0}$ varies mostly between -0.2 and -5 . Lower absolute values $(-0.03$ to -0.10$)$ are obtained within the kernels. Values of $b_{0}$ different from zero do not mean that in the first moment following transfer $T_{1}$ is different from $T_{i}$; it means only that extrapolation of the linear model (after transformation) to time zero is not valid : the drop of temperature is more rapid during the first moments, then the rate of cooling stabilizes.

\section{Thermal diffusivity}

Models of a homogeneous cylinder (CARSLAw \& JAEGER, 1959 ; SCHNEIDER, 1955) show the ratio of $\mathrm{X}_{1} / \mathrm{X}_{2}$ to be approximately constant through time (ratio of $\mathrm{X}$ values measured at a given time in two different locations 1 and 2 , situated within the ear at a distance $r_{1}$ and $r_{2}$ from the central axis). In our case, the two locations were the kernels and the center of the cob. From values of $b_{1}$ and from values of the ratio of $\mathrm{X}_{1} / \mathrm{X}_{2}$ CARSLAW \& JAEGER (1959) suggest obtaining crude first estimations of thermal diffusivity (a) using :

$$
\mathrm{a} \simeq-\mathrm{b}_{1} \mathrm{r}^{2} / \mathrm{Mn}^{2}
$$

where $\mathrm{Mn}$ is given by $\mathrm{X}_{1} / \mathrm{X}_{2}=\mathrm{J}_{0}\left(\mathrm{Mn} \mathrm{r}_{1} / \mathrm{r}_{2}\right)$ (CARSLAW \& JAEGER, 1959). $\mathrm{J}_{0}(\mathrm{x})$ is the zero order Bessel function of the first kind, and $r_{1}$ is the total radius of the cylinder. This method was used for each ear separately. Calculations were made for a subsample of 23 ears in exp. 2. The experimental values $X_{1} / X_{2}$ tended to increase with time, but when values obtained during the first minutes were ignored the variation of $\mathrm{X}_{1} / \mathrm{X}_{2}$ through time remained within $15 \%$. The constant value of $\mathrm{X}_{1} / \mathrm{X}_{2}$ required by the model was taken as the slope of the orthogonal regression line of $X_{1}$ over $X_{2}$ (DAGNELIE, 1969). Mean values of $b_{1}$ and $a$ (thermal diffusivity) over ears were calculated. The number of ears measured is indicated in table 5 . These estimates are very crude due to the method of estimation (which gives only approximate values) and to the heterogeneity of ears that contain three layers (husk, grain, cob) and therefore do not correspond to the model of an homogeneous cylinder.

\section{Other thermal characteristics}

Crude estimations of thermal capacity $\mathrm{c}\left(\mathrm{J} \mathrm{kg}^{-1}{ }^{\circ} \mathrm{C}^{-1}\right)$ were made calorimetrically on three ears, and on samples of $250 \mathrm{~g}$ grains, $50 \mathrm{~g}$ cobs, $50 \mathrm{~g}$ husks (cut into pieces) from exp. 1. Specific weight $(\rho)$ was measured on nine ears (exp. 2) determining the volume of each ear part by immersion. Thermal conductivity $k\left(\mathrm{~J} \mathrm{~h}^{-1}\right.$ $\mathrm{m}^{-1}{ }^{\circ} \mathrm{C}^{-1}$ ) was calculated from $\mathrm{k}=\mathrm{a} \mathrm{c} \rho$ using the mean value obtained for a. (SCHNEIDER, 1955).

\section{RESUITS}

\section{A. Effect of low temperature on subsequent kernel growth}

1. Submitting kernels for $45 \mathrm{~min}$ to a temperature of $-2{ }^{\circ} \mathrm{C}$ ( -1 to $-3{ }^{\circ} \mathrm{C}$ measured at kernel surface) did not prevent grain filling from continuing after treatment (table 3 ).

2. A significant reduction (re) of subsequent kernel growth rate was however observed in nearly all cases. Reductions (re) of 10 to $35 \%$ were observed (average $22 \%$; table 3 ). Strangely enough the two lowest reductions (about $10 \%$ ) were observed with treatments at the lower dry-matter contents (less than $20 \%$ in exp. 2.1, 2.2) whereas one of the highest reduction $(33 \%)$ was observed in an experiment where the grain was among the driest $(45.6 \%)$ exp. 3.2 at time of treatment application. Other results do not indicate a clear relationship between reduction of kernel growth

TABLE 3

Effect of light frost on subsequent kernel growth.

Effet d'une gelée légère sur la croissance du grain.

\begin{tabular}{|c|c|c|c|c|c|c|c|c|c|c|}
\hline \multicolumn{2}{|c|}{$\begin{array}{l}\text { Experiment }^{1} \\
\text { Expérience }^{1}\end{array}$} & \multirow[t]{2}{*}{$\begin{array}{l}1 \% \text { DM when } \\
\text { treated } \\
\% \text { MS lors du } \\
\text { traitement }\end{array}$} & \multirow[t]{2}{*}{$\begin{array}{l}\text { PGAA }^{2} \\
\text { PGAA }^{2}\end{array}$} & \multicolumn{2}{|c|}{$\begin{array}{l}\text { Final kernel weight } \\
\text { in control (mg) } \\
\text { Poids final par grain } \\
\text { (témoins) } \\
\text { (mg) }\end{array}$} & \multirow{2}{*}{$\begin{array}{l}\text { Reduction }{ }^{4} \text { of final } \\
\text { kernel weight }(\%) \\
\text { Réduction }{ }^{4} \text { du poids } \\
\text { final par grain } \\
(\% 0) \text { Re }\end{array}$} & \multicolumn{2}{|c|}{$\begin{array}{c}\text { Kernel growth rate } \\
\text { mg day } \\
\text { Taux de croissance } \\
\text { du grain }\end{array}$} & \multicolumn{2}{|c|}{$\begin{array}{l}\text { Reduction }{ }^{4} \text { in kernel } \\
\text { growth rate }(\%) \\
\text { Réduction }{ }^{4} \text { du taux } \\
\text { de croissance } \\
\text { du grain }\end{array}$} \\
\hline & & & & & & & $\mathrm{C}^{5}$ & $\underline{T}^{\zeta}$ & & \\
\hline \multicolumn{2}{|l|}{1} & 50.0 & 94 & 265 & $(12.8)^{3}$ & 1.4 & 5.70 & $4.42(0.397)^{3}$ & $* * 6$ & 22.5 \\
\hline \multirow[t]{3}{*}{2} & 2.1 & 15.3 & 12 & 186 & $(5.8)$ & 10.8 & 5.81 & $5.10(0.231)$ & $*$ & 12.2 \\
\hline & 2.2 & 18.0 & 20 & 144 & $(5.5)$ & 9.4 & 5.62 & $4.96(0.260)$ & $*$ & 11.7 \\
\hline & 2.3 & 39.1 & 77 & 144 & $(8.4)$ & 6.6 & 5.43 & $3.83(0.266)$ & NS & 29.2 \\
\hline \multirow[t]{2}{*}{3} & 3.1 & 37.8 & 49 & 240 & $(10.0)$ & 12.5 & 6.85 & $5.18(0.458)$ & $* *$ & 24.4 \\
\hline & 3.2 & 46.6 & 69 & 218 & $(10.3)$ & 10.4 & 6.87 & $4.60(0.458)$ & $* *$ & 33.0 \\
\hline \multirow[t]{2}{*}{4} & 4.1 & 31.6 & 51 & 215 & (11.9) & 17.3 & 4.84 & $3.14(0.266)$ & $*$ & 35.1 \\
\hline & 4.2 & 37.3 & 75 & 173 & $(7.2)$ & 6.6 & 3.10 & $2.29(0.206)$ & $*$ & 26.3 \\
\hline
\end{tabular}

\footnotetext{
1 See table 2 ; voir tableau 2.

2 Proportion of growth already achieved at time of treatment (kernel weight/final kernel weight in controls) ; proportion de la croissance du grain déjà réalisée lors du traitement (poids du grain/poids final du grain chez les témoins).

${ }^{3} \sigma_{\bar{x}}$ Standard error of the mean : erreur standard des movennes présentées.

4 Relative to controls; par rapport aux témoins.

5 C Control (témoin); T treated (traité).

6 Level of significance of treatment effect ; niveau de signification: ${ }^{*} \mathrm{p} \leqq 0.01: *^{*} \mathrm{p} \leqq 0.5$; NS not significant $\mathrm{p} \leqq 0.05$; NS non significatif $\mathrm{p} \leqq 0.05$.
} 
TABLE 4

Effect of frost $\left(-5{ }^{\circ} \mathrm{C}\right.$ at kernel surface) on subsequent kernel growth.

Effet d'une gelée $\left(-5^{\circ} \mathrm{C}\right.$ à la surface du grain) sur la croissance ultérieure du grain.

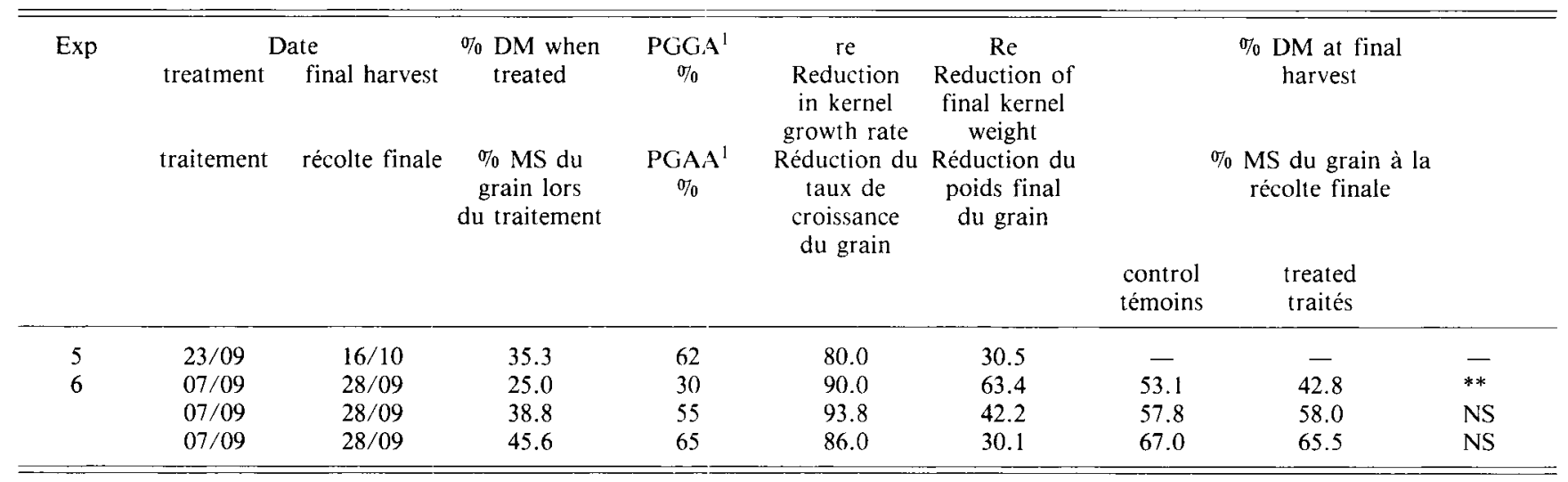

${ }^{1}$ See explanations in table 2 ; voir les explications dans le tableau 2.

rate (re) and grain dry matter content at the time of treatment (table 2). Reduction of final kernel weight varied from 1 to $17 \%$, depending on the amount of growth already achieved (PGAA) at the time of treatment (table 3).

Submitting kernels for 45 min to lower temperatures $\left(-5^{\circ}\right.$ at distal surface of kernels, $-3^{\circ}$ in center of cob) had drastic effects on kernel growth rate at all kernel dry matter contents tested ( 25 to $52 \%$ DM) : a reduction of $80-90 \%$ being observed in all cases. A selection of results is presented in table 4 . In the case where kernel growth was practically stopped by the treatment, the effect of frost on final kernel weight was markedly dependent on kernel weight already achieved at the time of treatment.

3. Dry matter content of the kernels at final harvest was not influenced by the treatment $\left(-2^{\circ}\right.$ or $-5{ }^{\circ} \mathrm{C}$ ). Kernels of treated ears showed some tendency to display lower dry matter content but this was not general and the differences were not significant. Only in one case, when $-5{ }^{\circ} \mathrm{C}$ was applied at low dry matter content $(25 \%)$, there was a significant difference between treated plants $(42.8 \% \mathrm{DM}$; table 4$)$ and controls $(53.1 \%)$.

4. The continuous decrease of temperature with the $-2{ }^{\circ} \mathrm{C}$ treatment indicates that supercooling took place whereas in the case of a treatment at $-5{ }^{\circ} \mathrm{C}$ a transient exotherm indicated formation of ice within the kernels. When temperature was around $-3{ }^{\circ} \mathrm{C}$ supercooling or ice formation were observed according to the case.

\section{B. Thermal characteristics of ears}

Mean values of $b_{1}$ (slope of $\ln X$ during cooling) are presented in table 5. An overall mean of $-138 \times 10^{-4} \mathrm{~min}^{-1}$ was observed with large variations. This means it took on average $45 \mathrm{~min}$ for temperature to drop from $25^{\circ}$ to about $15^{\circ}$, and $90 \mathrm{~min}$ to approach $10^{\circ}$. After $2 \mathrm{~h}$ the temperature was still above $8{ }^{\circ} \mathrm{C}$. Extrapolating this, it would take more than $4 \mathrm{~h}$ to approach approximately $5^{\circ} \mathrm{C}$. After the first $10 \mathrm{~min}$ the curves of $\mathrm{X}$ obtained for cobs and within grains were very similar (the difference of temperature was less than $1{ }^{\circ} \mathrm{C}$, fig. 2). However due to small differences in intercept a difference of 1 to $3{ }^{\circ} \mathrm{C}$ was observed between the surface of the grains and the centre of the cob (fig. 2).

The mean value of thermal diffusivity obtained on a subsample of 23 ears (exp. 2) was a $=417 \times 10^{-6} \mathrm{~m}^{2}$ $\mathrm{h}^{-1}$ (with $\overline{\mathrm{x}}=52 \times 10^{-6}$ ). This value is intermediate between those reported for water $\left(518 \times 10^{-6} \mathrm{~m}^{2} \mathrm{~h}^{-1}\right)$ and pine wood perpendicularly to the axis of the fibres $\left(269 \times 10^{-6} \mathrm{~m}^{2} \mathrm{~h}^{-1} ;\right.$ KREITH, 1967).

The high variability of the estimates (obtained per

TABLE 5

Slope $b_{1}$ of regression of $X^{l}$ on time (min) during cooling.

Pentes $b_{l}$ de la régression de $X^{l}$ en fonction du temps (mn) durant le refroidissement.

\begin{tabular}{|c|c|c|c|}
\hline 2 & & $\overline{\mathrm{b}}_{1}^{3} \quad \sigma_{\overline{\mathrm{b}}}$ & $\mathrm{n}$ \\
\hline Kernel surface & $\exp 1$ & $131 \pm 13,6$ & 35 \\
\hline (surface du grain) & $\exp 2$ & $182 \pm 15,3$ & 31 \\
\hline $\begin{array}{l}\text { Within kernel } \\
\text { (intérieur du grain) }\end{array}$ & $\exp 2$ & $127 \pm 5,9$ & 34 \\
\hline Centre of the $\mathrm{cob}$ & $\exp 1$ & $136 \pm 10,3$ & 33 \\
\hline (centre de la rafle) & $\exp 2$ & $118 \pm 3,9$ & 34 \\
\hline
\end{tabular}

${ }^{1} \mathrm{X}=\ln \left[\left(\mathrm{T}_{\mathrm{t}}-\mathrm{T}_{\mathrm{a}}\right) /\left(\mathrm{T}_{\mathrm{i}}-\mathrm{T}_{\mathrm{a}}\right)\right]$

where $T_{1}$ is temperature at time $t$

$\mathrm{T}_{\mathrm{i}}$ is initial ear temperature $\left(25^{\circ} \mathrm{C}\right)$

$T_{a}$ is air temperature $\left(5^{\circ} \mathrm{C}\right)$.

2 location of probe within ear for determination of $T_{t}$.

${ }_{3} \bar{b}_{1}$ mean of $b_{1}$ (each $b_{1}$ is determined on one ear) in $\min ^{-1} \times 10^{-4}$ $\sigma_{\bar{b}}$ standard error of $\bar{b}_{1}$

$n$ number of ears measured.

$T_{t}$ est la température au moment $t$

$\mathbf{T}_{j}$ est la température initiale de l'épi $\left(25^{\circ} \mathrm{C}\right)$

$\mathrm{T}_{\mathrm{a}}$ est la température de l'air $\left(5^{\circ} \mathrm{C}\right)$.

2 Situation de la sonde à l'intérieur de l'épi pour la détermination de $T_{\text {. }}$.

$3{ }^{3} \bar{b}_{1}$ est la moyenne de $b_{1}$ (chaque $b_{1}$ est déterminé sur un épi) en $\mathrm{mn}^{-1} \times 10^{-4}$

$\sigma_{\bar{b}}$ esi l'erreur standard de $\bar{b}_{1}$

$n$ est le nombre d'épis mesurés. 
ear individually) made it impossible to find any consistent relationship with dry matter content.

Thermal capacity was found to be similar for the different parts of the ear measured ( 2.5 to $2.9 \times 10^{-3}$ $\mathrm{J} \mathrm{kg}^{-1}{ }^{\circ} \mathrm{C}^{-1}$ ) with estimates of $2.6 \times 10^{-3} \mathrm{~J}$ $\mathrm{kg}^{-1}{ }^{\circ} \mathrm{C}^{-1}$ for whole ears $(57 \% \mathrm{DM})$. The specific weight of the small subsample of ears measured was $550 \mathrm{~kg} \mathrm{~m}^{-3}$ but the specific weights of the different parts differed markedly: values of 1150,640 and $123 \mathrm{~kg} \mathrm{~m}^{-3}$ were found for kernel, cob and husk layer (with air enclosed).

In this regard it was noted from observation on 7 varieties that air enclosed between the husk leaves (13 on average, forming 6 to 9 layers) represented an average $8 \%$ of the total ear volume (ear + husk). The thickness of the husk layer corresponded roughly to the diameter of the cob, whereas the thickness of the kernel layer was twice as large.

Finally from the previous estimates the thermal conductivity of whole ears (with husk) was calculated as $600 \mathrm{~J} \mathrm{~h}^{-1} \mathrm{~m}^{-1}{ }^{\circ} \mathrm{C}^{-1}$.

\section{DISCUSSION AND CONCLUSION}

Kernel growth in maize was reduced after kernels were submitted to low temperature for $45 \mathrm{~min}$. The effects observed were consistent with the view that temperatures of $-4{ }^{\circ} \mathrm{C}$ or lower cause serious damage to immature kernels (kernels with dry matter content lower than $60 \%$ ). Moreover higher (less drastic) subzero temperatures were not without effect, in our experiments. In the absence of ice formation in the kernels during treatments at $-2{ }^{\circ} \mathrm{C}$, these effects would correspond to a type of chilling injury (damage caused by low temperature, without actual freezing of tissues
(LEVITT, 1980). Various types of chilling injury are known to occur in maize, at low temperatures, even well above zero (BOURDU, 1984) and they seem to be related to disfunction of membrane (MIEDEMA, 1982) or membrane-bound enzymes. From their entrance in the kernel through the pedicel, until their deposition as starch, assimilates go through different steps (WOLSWINKEL, 1985). One or several of these stages, enzymecatalyzed reactions involved in sucrose utilization for starch formation, or energy metabolism within the kernels are all steps or processes where deposition of storage material may be limited (DUFFUS \& DUFFus, 1984), and possibly affected by chilling injury. It is beyond the scope of this work to infer further about mechanisms involved. Direct damage to kernels may occur at low temperature although the thermal characteristics of ears indicate they are relatively well protected against rapid and brief drops in temperature. Also, in reality, protection might be less than expected from observations of speed of cooling in controlled conditions since other factors such as radiation cooling, convective cooling, propagation of frost from more exposed and therefore cooler plant parts, external ice nucleation all play a role.

Moreover, in nature, variations of temperature are more progressive and the differences between air temperature and ear temperature are small. The effects of subzero temperature depend on the rate of temperature change (during cooling and thawing; LARCHER et al., 1985). Our treatment reproduced the changes in temperature normally occurring in nature only for temperatures lower than $5{ }^{\circ} \mathrm{C}$. We do not know the effect of rate of temperature change during the first part (above $5{ }^{\circ} \mathrm{C}$ ) of the cooling treatment. This will be investigated in further work.

\section{REFERENCES}

Banath C. L., Single W. V., 1976. Frost injury to wheat stems and grain production. Aust. J. Agric. Res., 27, 749-733.

Barloy J., 1984. Phase germination, levée et implantation, 13-48. In Gallais A. : "Physiologie du mais ». Communications au Colloque Physiologie du maïs, organisé par l'I.N.R.A., le CNRS et l'AGPM, Royan, mars 1983, I.N.R.A., Paris.

Bourdu R., 1984. Bases physiologiques de l'action des températures, 389-424. In Gallais A. : "Physiologie du mais ». Communications au Colloque Physiologie du maïs, organisé par l'I.N.R.A., le CNRS et l'AGPM, Royan, mars 1983, I.N.R.A., Paris.

Carslaw H. S., Jaeger J. C., 1959. Conduction of heat in solids (2 ed.). Clarendon Press, Oxford. 510 p.

Dagnelie P., 1969. Théorie et méthode statistiques. Applications Agronomiques, Vol. 1, Duculot, Gembloux, 378 p.

Daynard T. B., Tanner J. W., Hume D. J., 1969. Contribution of stalk soluble carbohydrates to grain yield in corn, Zea mays L. Crop Sci., 9, 831-834.

Daynard T. B., Baron V. S., Tollenaar M., 1980. Points of current interest in studies of the physiology of the maize plant, 205-215. In
Bunting E. S. : "Production and utilization of the maize crop". Proc. of the First European Maize Congress, Euromais 1979, Cambridge. The Hereward \& Stourdale Press, Ely and Packard Publishing Ltd., Chichester.

Draper N. R., Smith H., 1968. Applied Regression Analysis. Wiley J., New York, 407 p.

Duffus C. M., Duffus J. H., 1984. Carbohydrate metabolism in plants. Longman, London, $183 \mathrm{p}$.

Edey S. N., 1975. Probability of freezing temperatures in the spring and fall in the atlantic region. Publication 1565, Canada Department of Agriculture.

Faucher M., Bonnemain J. L., 1981. Action de barrières thermiques sur la circulation libérienne chez le mais (Zea mays L.). Physiol. vég., 19, 379-390.

Judd R., Tekrony D. M., Egli D. B., White G. M., 1982. Effect of freezing temperatures during soybean seed maturation on seed quality. Agron. J., 74, 645-650.

Kreith F., 1967. Transmission de la chaleur et thermodynamique Masson et Cie, Paris, $657 \mathrm{p}$. 
Larcher W., Häckel H., Sakai A., 1985. Die nichtparasitären Krankheiten. 5 Teil : "Meteorologische Pflanzenpathologie, Witterung und Klima als Umweltsfaktoren, Kälte und Frost". Paul Parey, Berlin, $326 \mathrm{p}$.

Levitt J., 1980. Response of plants to environmental stress. I. Chilling, freezing and high temperature stresses. Academic Press, Orlando.

Miedema P., 1982. The effects of low temperature on Zea mays. Adv. Agron., 35, 93-128.

Rossman E. C., 1949. Freezing injury of inbred and hybrid maize seed. Agron. J., 41, 574-583.
Schneider P. J., 1955. Conduction heat transfer. Addison-Wesley Publishing Cy, Reading, $395 \mathrm{p}$.

Single W. V., Marcellos H., 1974. Studies on frost injury to wheat. IV. Freezing of ears after emergence from the leaf sheath. Aust. $J$. Agric. Res., 25, 679-686.

Struik P. C., 1983. The effects of short and long shading, applied during different stages of growth, on the development, productivity and quality of forage maize (Zea mays L.). Neth. J. agric. Sci., 31, 101-124

Wolswinkel P., 1985. Phloem unloading and turgor-sensitive transport : factors involved in sink control of assimilate partitioning. Physiol. Plant., 65, 331-339. 